\title{
Family Planning and Participation in Family Planning Programs for Couples Early Marriage
}

\author{
$1^{\text {st }}$ Ali Imron \\ Sociology Department \\ Faculty of Social Sciences and Law \\ Universitas Negeri Surabaya \\ Surabaya, Indonesia \\ aliimron@unesa.ac.id
}

\author{
$2^{\text {nd }}$ Arief Sudrajat \\ Sociology Department \\ Faculty of Social Sciences and Law \\ Universitas Negeri Surabaya \\ Surabaya, Indonesia \\ ariefsudrajat@unesa.ac.id
}

\author{
$3^{\text {rd }}$ Pambudi Handoyo \\ Sociology Department \\ Faculty of Social Sciences and Law \\ Universitas Negeri Surabaya \\ Surabaya, Indonesia \\ pambudihandoyo@unesa.ac.id
}

\begin{abstract}
This study aims to identify the causes of women marrying at an early age and participation in family planning programs. Field findings indicate the causes of women in Klampis Subdistrict, Bangkalan Regency, were married at an early age, partly due to factors of education, economy, and sociocultural conditions. Construction of the community still considers that education is not an important aspect. In terms of sociocultural, the construction of society in general, which considers that a woman must be married immediately for reasons to save the family's self-esteem as an effort to avoid children from promiscuity. The strength of patriarchal culture places women in a very low bargaining position. After marriage, a new phenomenon emerged, namely discrimination and the practice of violence against women, such as physical violence and symbolic violence. Regarding family planning, the wife wants to have two children, but the husband wants more than two children with the distance between children is not too close. Parents of informants have a big influence on the process of determining the number of children. From the aspect of participation in the family planning program, informants have a low awareness of participating in family planning because they are afraid of damaging their contents. However, for informants who took part in family planning with the reason that they no longer have children. The actors who influence the decision-making process to join the family planning program are husband and parents.
\end{abstract}

Keywords-Family; KB; Early Marriage

\section{INTRODUCTION}

Population is a strategic factor in the implementation of national development because of some rationalization. First, the population is the center of all development policies and programs carried out. Second, the existing population conditions greatly affect the dynamics of development. Third, the emergence of change as a consequence of the new population dynamics will be felt in the long term, so often the important role of the population in development is neglected [1].

Population growth is based on three main elements, namely fertility, mortality and migration. The fertility rate has a positive influence on the population growth rate, while the mortality rate has a negative influence on the population growth rate. The migration factor has a positive or negative effect, depending on a large number of people entering and exiting in an area [2].

The fertility rate is influenced by social, cultural, economic, and children's values. Richard [3], revealed that fertility rates are part of a very complex system in the social, biological, and interaction fields with environmental factors. Determination of the high and low level of a person's fertility, the decision taken by the wife or husband and wife or widely by the family.

Although the Family Planning program (KB) is specifically not included in the 2015 MDGs, family planning programs have proven to be able to reduce population growth and decrease the national Total Fertility Rate (TFR). As the structure of government changes from centralization to decentralization, which gives autonomy to regions with all the authority to manage their regions independently. Local governments are only concentrated on economic growth, while population development is neglected. This condition can be seen from Indonesia's TFR which has increased from 2.26 at SUPAS 2005 to 2.6 in the 2007 IDHS. Meanwhile, in the 2010 Population Survey, TFR Indonesia stagnated at 2.6 [4].

TFR is influenced by social and cultural dimensions. This will have an impact on family planning aspects. The desire of each family to immediately have children will encourage increased fertility in a family, including new families who marry at an early age. Young marriage is a teenage marriage seen in terms of age is still not enough or immature where in Act No. 1 of 1974 article 71, which sets the maximum limit of marriage at a young age is 16 years old woman and 19 years old man has just may marry [5]. Whereas the $B K K B N$ gives the ideal age limit for a person to get married is above 20 years for women and above 25 years for men [6].

Balitbangkes [7], shows that young women in Indonesia aged 10-14 are married as much as $0.2 \%$ or more than 22,000 young women aged 10-14 in Indonesia are married. The number of young women aged 15-19 who are married is greater than that of young men aged $15-19$ years $(11.7 \%$ of women versus $1.6 \%$ of men). Whereas among female age 
groups 20-24 years, more than 56.2\% are married. Data from the BPS (2010) shows that in Indonesia the percentage of marriages is quite high at $47 \%$ of women who are married under the age of 18 . The percentage of women married at the age of $10-15$ years is $13.4 \%$, while at the age of $16-18$ years $33.4 \%$ [4].

The phenomenon of early marriage tends to increase, one of which occurred in the Bangkalan Regency. Data from the Depag Bangkalan recorded in the Marriage Wills Note Book, stated that the number of early marriages in Bangkalan Regency was 138 couples who were under 20 years old [8].

The phenomenon of early marriage also often occurs in other Madurese areas, one of which is in Sampang Regency. During the period of 7 years (2006-2013), there were 7 early marriages. Of the seven couples under the age of 20 [9]. Factors that encourage the reality of early marriage include economic factors and the family's good name.

As in Sampang, in Pamekasan there is often a marriage at a young age. Marriage at a young age often results in divorce by reason of incompatibility with their partners, feeling no longer in harmony, and difficulties in meeting family needs [10]. In line with the reality that occurred in Pamekasan, in the Sumenep Regency region, the phenomenon of early marriage seems to be a tradition that is difficult to deconstruct. Common factors such as weak economic conditions, low levels of education, strong motivation to avoid adultery practices, and matchmaking, are common causes of early marriage practices. However, the people of Sumenep still consider that holding a marriage at an early age will ease the parents' economic burden and save children from the risk of promiscuity [10].

Another phenomenon that needs to be considered related to early marriage is the fertility rate of young age groups (ASFR 15-19). Based on the 2012 IDHS data, along with the decline in TFR, in the same period, ASFR showed a decline in almost all age groups despite different speeds. In 1991, a very young birth rate (15-19 years) was still quite high at around 67 per 1000 women of that age. This figure was successfully suppressed significantly in the period of 2002 to 51 and continued to decline to 48 per 1000 women in 2012.

Kingsley Davis and Judith Blake conducted a sociological analysis of fertility. Davis and Blake suggested factors that affect fertility, which is referred to as "intermediate variables" [11]. According to him, social, economic and cultural factors that affect fertility will go through "intermediate variables". Whereas Freedman revealed that the variables that directly affect fertility are also basically influenced by the norms prevailing in society. In the end, a person's fertility behavior is influenced by existing norms, namely the norm about the size of the family and the norm about the intermediate variable itself. Furthermore, the norms about the size of the family and the intermediate variables are influenced by the level of mortality and socio-economic structure in the community [12].

Based on this phenomenon, this article aims to describe family planning and participation in family planning programs in families of early marriage in Klampis Subdistrict, Bangkalan Regency.

\section{RESEARCH METHODS}

This study uses a qualitative method. Qualitative research methods are research methods that intend to understand the phenomenon of what is experienced by the subject of research, such as behavior, perception, motivation, and action. This research is a descriptive research that aims to photograph various phenomena that arise in the community, which is the object of the research. This research was conducted in Bragang Village, Klampis District, Bangkalan Regency and lasted for 3 (three) months, starting from August to October 2015.

The subjects in this study were married couples who married at an early age, parents from the women (wives), and community leaders. Subjects were selected purposively based on considerations to understand the causes of early marriage, family planning, and participation in family planning programs.

Data collection is done by extracting primary data and secondary data. Extracting primary data is done through observation and in-depth interviews. While secondary data is explored through searching books; scientific articles, both published through journals; mass media reports; statistical data, and research results related to the problems studied. Data analysis techniques in this study use the interactive model Miles and Huberman, through the process of data reduction, data presentation, and conclusion drawing/verification.

\section{RESULTS AND DISCUSSION}

\section{A. Dating Experience}

Based on the results of a field data search, the majority of informants claimed that before marriage, they never dated anyone. The majority of them are immediately married to their current partners, even they are only briefly acquainted with their respective partners. Among those who met via social media Facebook, then exchanged cellphone numbers. After meeting for two months, they decided to get engaged then married.

There are also those who have banked but have to stop in the middle of the road for some reason, then get engaged again then get married. There were also those who met at the place they worked then engaged for four months and decided to get married. The average age of their marriage is one year, some have children, but some are still pregnant. There are also informants who are still delaying having children. Divorce cases also often occur among couples who marry early. There were among the informants whose marriages were only five months old and then divorced.

The factors that cause divorce are socio-economic conditions and incompatibility between husband and wife due to weak communication. Another factor is because the introductory process is only for a short time so they do not 
have a comprehensive understanding of their partners. In addition, divorce can occur due to age. At the age of teenagers, informants are still unstable and not fully mature between the two.

\section{B. Married and Post-Married}

Marriage between couples with each other has a different story. There are informants who have a harmonious relationship from the beginning of marriage to having children. However, not all marriages can end beautifully, there is violence committed by couples and marital relationships that are not harmonious from the start, because they do not know each other, and finally choose a way to separate or divorce. Many couples find a harmonious relationship because they already know each other and before marriage, they are dating. Whereas couples who end in divorce, the majority are caused by arranged marriages by their parents.

After marriage, the majority of young married couples who were successfully interviewed chose to live in the parents' house (matrilokal). This is because, in addition to not having their own housing, the parents of the wife do not want to part with the child for several reasons, such as a husband who does not have a permanent job and is unable to meet household needs, so that the parent feels responsible for fulfilling those needs. There are also couples who live in the wives 'parents' homes because parents are working abroad as TKI/TKW so they occupy the house. During living in an old home, often these early married couples experience intervention from parents.

The life of each post-married couple is different, some are harmonious and romantic, but some are lacking in terms of both economic and mental. Abusive treatment from husbands to wives is also often encountered. Since following her husband migrating in Jakarta, his wife has been treated very often harshly, from the words that were not well spoken by the husband to his wife until the treatment began from throwing to beating. The wife claims that she often experiences domestic violence. However, the wife does not have the strength to fight the husband. In these conditions, the wife is always subject to subordination. The husband's activities after finishing work are unknown to the wife, when he returns home the wife finds her husband drunk and unconscious.

Post-divorce life is increasingly difficult, they have to make a living on their own, there are those who work outside the region, such as Surabaya to work in a shoe factory or Jakarta and even work as migrant workers in Malaysia. Return to my hometown only on Eid al-Fitr or once a year. In terms of child care, they leave their children with parents at home.

\section{Pregnancy and Childbirth}

When the wife was pregnant, many informants decided to return to Madura. This is because the parents of the informants are worried about the needs of pregnant women who cannot be accessed by informants in the overseas area. When the informant became pregnant and returned to Bragang Village, the daily needs of the informants were borne by their parents, from daily food needs to parenting clothes. This is because the informant does not have a private house, so he is still riding in his parents' house.

The informant said he wanted to give birth to a baby normally in the local village midwife. While the distance desired by the informant between the first child and the second child is four years. Uniquely, informants want to have only two children. This is because the informant does not want to have many children, afraid of the hassle and certainly requires a lot of money. However, there were also informants who still wanted more than two children. They still have a strong belief that having many children will also increase fortune. "Children bring their fortune", catch one of the informants. If the child has grown up the informant does not want to curb his child, the informant lets his children grow according to their wishes. Regarding the issue of education, informants want their children to be educated higher than their parents so that their children will not only be able to work as farmers.

Meanwhile, according to Halimah [13], preferring to have a maximum of two children and the distance between 1 to 2 years. The informant also wanted to give birth normally to the village midwife. According to him, the process before deciding to have two children first consulted with the husband. The informant wants to have only two children for reasons not to bother. If you have more than two children, there will be a lot of expenses and business. There are also informants who do not want to rush to have children. They want to delay first by reason of wanting to raise money first. According to the informant how to postpone it by taking part in family planning.

From the parent's side, Mutimah (30), for example, after her child is married she wants her child to postpone pregnancy by taking part in family planning. However, the social construction that emerged in the community said that when using contraception before having children, it would be at risk for the womb. In addition, the informant hopes to have two grandchildren whose first grandchild is a man. The rationale is that if you have a granddaughter, you will be burdened with buying jewelry. While other parents, Masnin (55), revealed that he wanted to have many grandchildren. He believes that whatever the number of children is the gift of God Almighty. The informant wanted his first grandson to be male.

Regarding pregnancy and birth, according to the village midwife Bu Musayyanah (30), usually Bragang village women who will give birth use their services by visiting the midwife's house. Whereas in Bragang Village there were no dukuns. If there are obstacles in the birth process beyond the ability of the midwife, it will usually be referred to the Bangkalan Hospital, accompanied by a midwife. According to the informants who were interviewed, there were informants who had miscarried twice, namely when there were two months of age and there was only one month nine days of pregnancy. 
According to informants, Bragang Village residents have not been maximal in the family planning program. The people who come to the midwife's house who are going to have family planning are women who are in childbearing age, which is between 15-25 years. The average family planning acceptor uses injectable types, both for one month and three months. The tariff for one-month injection type $\mathrm{KB}$ services is IDR 25,000, while the injection type $\mathrm{KB}$ with a term of three months is IDR 20,000. Side effects from the use of injectable type contraceptives vary, including increased body weight, increased appetite, dizziness, and nausea. Related to the implementation of family planning in Bragang Village, according to the Head of Bragang Village, Busiri (45), family planning counseling is often carried out sometimes once a month or once every three months and the surrounding community begins to open up with these counseling because they feel that they are beneficial for themselves. charged.

According to the village midwife, how to convince residents to use certain types of family planning through several strategies. There are those who ask themselves, some sometimes just get married, want to have family planning for three months because they are afraid of their womb drought. Postpartum women prefer to take pills first. Most KB users are from ordinary citizens, while kiai families do not agree with the existence of the KB program. The Kiai still considers and has a strong belief that "many children, lots of sustenance" with the reason that God sustains sustenance and attaches to each of his people.

According to the Bragang Village midwife, women in Bragang village who average birth age are 16-19 years old. The informant stated that there were many residents who had the awareness to give birth to midwives, although there were still those who gave birth to traditional birth. In Bragang Village there are currently two midwives and two nurses. According to the village midwife, the risk of giving birth to an early age is when the uterus is not ready for pregnancy, menstruation is not smooth, miscarriages occur, some are even born prematurely.

In relation to cases of unwanted pregnancy (KTD), according to informants, there was an incident of pregnancy outside of marriage in Bragang Village. To avoid the case, it must be immediately married if it has been dating for a long time. There are concerns from parents about their long-dated child. Parents are worried about an unwanted pregnancy. Similar information was also expressed by the Secretary of Bragang Village, Haris (44), that in Bragang Village there had been four unmarried pregnancies. To prevent this incident from happening, the village made a time limit for visiting the night.

\section{Socio-Cultural Characteristics}

A socio-cultural condition of society will greatly affect a cultural tradition in the region, namely whether a particular culture is still being carried out, or has already begun to be abandoned due to the entry of foreign cultures that influence the order of social life and culture of the local community. Some still practice a habit for traditional reasons and because of social and economic factors. The perpetrators of early marriage, especially women, are the original residents of Bragang Village.

After getting married, the majority of Bragang Village women followed their husbands out of the area, such as Jakarta, Surabaya and Bondowoso and even to Malaysia to become Indonesian Migrant Workers (TKI). There they help the husband work or just accompany her husband in the area. In the context of belief or religion, the Bragang Village community embraced Islam. This can be seen from the existence of religion-based schools (madrasas) from elementary to the high school level. The number of people who have studied pesantren outside the village, especially women who have been educated from the very beginning with strong religious knowledge.

A large number of Bragang Village people who work outside the area is due to lack of employment in the village, with infertile natural conditions, and low education. Even though it looks deficient in the area, but in reality, in their hometown, they can make large houses and buy motorized vehicles for families in the village. This reflects that the work ethic of the residents of Bragang Village is very strong. Habits that may not be felt by the people of Bragang Village are marrying off girls at an early age (married age is out of stipulation). Where its citizens still believe in traditional myths or thoughts that are unreasonable.

The existence of early marriage in Bragang Village can also be caused by subsistence family economic conditions. Parents who marry their children at a young age consider that by marrying their children the economic burden of the family will decrease. This is because if the child is married, it will be the responsibility of her husband. Even parents hope that their children are married can help parents' lives.

\section{E. Early-age Marriage}

\section{1) Rationality of marriage}

Everyone must have the desire to get married if their life is well established and comfortable and ready to foster a household. There are some informants who choose to get married at a young age, namely between the ages of 15-18 years. Though most likely, when married at the age of a dozen, it is certainly not ready to be born physically and mentally, as well as an immature attitude. Teenagers who choose to get married at a young age (15-18 years) are caused by economic factors because both parents are no longer able to pay for school, but there are also because the child has no desire to go to school.

Bragang Village youth who choose to marry at the age of majority at their own will without coercion from both parents and the extended family. There are those who marry young because they are afraid of going out of wedlock so they prefer to get married early before something they don't want. Couples who have been married early or are married at a 
young age have been officially married at the Office of Religious Affairs (KUA), even though previously parents had to change the year of birth that was printed on the Family Card (KK).

\section{2) External factors}

To get married the parents of the male party must fulfill several conditions, including having to report to the RT and RW to request a cover letter, then to meet with the village head (klebun) to request a moving marriage certificate, then request a copy to the local KUA to KUA residence the woman. For women, it is enough to prepare various things needed to get married. Parents who have agreed to their children who want to get married early because of economic factors, there are also because they are no longer able to support their children to continue their education to a higher level, so many of them only go to elementary, middle and high school then directly married.

They prioritize work more than education, so their thinking as high as any school just wasted money and in the end the women were kept in the kitchen. There are also parents who approve their children to marry early because they are afraid of things that are not desirable, and because they are afraid of talking to their neighbors if they don't marry their children immediately.

The couples who marry themselves in Bragang Village actually know the ideal age of marriage for women, namely at the age of 19 years and above and for men who are aged 20 years and over. But still, they prefer to get married at the age of teens. Even though they understand that if they get married at a young age they are not ready to be physically and spiritually, and their age is still not ready to foster a household and to care for and teach good values and norms to their children in the future. However, because of economic factors, they choose to marry early because they are lazy to go to school and prefer to get married.

The informants who succeeded in being interviewed claimed that they had no desire to go to school and preferred to care for their children and husbands only. However, there are still those who wish to continue their education to a higher level, but they are ashamed of age who are no longer young so they decide not to continue school and choose to work. The majority of them work outside the city such as Jakarta, Banjarmasin and Bandung. Others work abroad such as Malaysia, Singapore, Saudi Arabia and Dubai as migrant workers. The majority of them work as drivers, cleaning services and fish sellers.

Among those who did not agree on early marriage. Those who disagree with early marriage argue that getting married at a young age is definitely not physically and mentally ready and besides that, they are also unstable, and they are still not ready to foster good households and take care of their children optimally. There are also those who argue that the womb of a woman who is still a dozen years old is still too weak and not strong enough so the possibility of a miscarriage is very large. For those who agree to the premature marriage, it is argued to avoid being pregnant outside of marriage, but it can also ease the burden on parents because after marriage they will definitely work out of town or abroad.

\section{F. Family Planning and Fertility Aspects}

\section{1) Child and child value}

Continuing offspring is one of the core goals of marriage. The desired number of children is something that must be shared between husband and wife to equate perception. Some informants who were successfully interviewed claimed to be aware of the number of children recommended by the government, namely two children. The heavier burden of life also affects the choice of married couples to determine the number of children desired. All of the female informants who were successfully interviewed wanted only two children or at most three children. Unlike the male (husband) informants who were successfully interviewed, they wanted to have many children. For him, more and more offspring, parents' lives will be calmer because their children who are already earning all will prosper their parents too.

While the female informant (wife) considered that raising a child was difficult because the cost of the need is now increasingly expensive, besides that they are afraid of the birth process that requires struggle, even between life and death, in addition to the pain that must be felt many times. The fear may be related to their youthful age and affected by the thought of the pain of labor.

The distance between the children desired by the informant does not want to be too close nor do they want to be too far away. They do not want to be too close to the age between children because it will be difficult to take care of children. They imagine the bad conditions that will occur if their brother is still small and his younger brother is also still small and will need more attention. For example, both must be supplemented with milk, and if their child is naughty they will irritate each day. The informant also wants the age range between children not too far away because they are afraid that parents will get older in taking care of their children and cannot be optimally given attention because of their old age. The thought process in determining the number of children is discussed with the husband, but there are those who have not thought too seriously about the number of children and handed them over to those in power. The influence of the parents of male informants and female informants had a major influence on the process of determining the number of children, besides the husband. Parents and husbands seem to agree that many children are a gift.

\section{2) Socialization in Children and Problem Solving}

Children are considered by informants as a blessing and sustenance from God Almighty. Therefore, the presence of the baby is always anticipated and is considered a thing to be grateful for. But in the process also must be considered everything related to the needs and fulfillment of the rights for the baby. The values and norms for children are also expected 
that husband and wife informants must also be internalized and socialized to their children, including the most important are good values and norms that are in accordance with religion.

The expected values and norms are to have faith in God and serve their parents. Informants apply these norms and values early on to their children by giving examples or good examples to their children. There is one case of an informant who has divorced her husband but already has one child from her. His son never knew who his father was until now because he was still a child. The boy always calls daddy to his grandfather. The informant said that one day he would tell the truth about his father. But at the right time later because the child is still small. The informants also have thought about the future of their children by continuing to work, by continuing to work and make money it can be their savings for children, such as the cost of childbirth, education and children's health.

\section{G. Participation in the KB Process}

\section{1) Rationality}

From the findings of the data obtained in the field, the residents of Bragang Village still have a low level of awareness to take part in family planning because they are afraid of damaging their contents. However, for informants who took part in family planning with the reason that there would be no conduction (speed) had more children. The influential actors in the decision-making process to join the family planning program are their families, especially their husbands and parents. The decision to follow or not take part in a family planning program is usually supported by all parties, including the informants themselves, husbands, even their extended families. However, other community groups, such as the kiai group, still believe in the belief of "many children, lots of sustenance". Knowledge construction like this is then internalized to the public that the community does not need to worry about the large number of children.

\section{2) Process and impact}

From the findings of the data obtained by residents, they prefer to take part in family planning programs in the village midwife or some choose to participate in the local health center. While the type of contraceptive that is the majority chosen is injectable family planning and some use pills. Costs incurred for participating in family planning programs vary depending on the type of contraceptive methods used. For injection-like contraceptives around Rp. 12,000 - Rp. 15,000, for pills around Rp. 7,000. The impact that arises after the use of family planning is to physically cause obesity and reproduce menstrual irregularities.

\section{CONCLUSION}

The phenomenon of marriage in Bragang Village is an increasingly complex picture of population conditions. Young women in Bragang Village show that marriage is at an increasingly young age. The cause of women in Bragang Village was married at an early age, among others due to the level of education, economy, and sociocultural conditions, where the three main factors had an attachment to one another. After the young women of Bragang Village got married, a new phenomenon emerged, namely discrimination and the practice of violence and ended in divorce. Regarding family planning and fertility, Bragang village women want two children or at most three children. While the husband wants to have many children to support the parents' economy later.

Bragang Village residents have a low awareness of participating in family planning because they are afraid of damaging their contents. Actors who are influential in the decision-making process for participating in family planning programs are families, especially husbands and parents. On the other hand, the kiai still has the keyaninan that "many children, lots of sustenance". Knowledge construction like this is then internalized to the public that the community does not need to worry about the large number of children.

\section{ACKNOWLEDGMENT}

Our thanks go to the Central BKKBN which has provided funding in this study.

\section{REFERENCES}

[1] P. Tjiptoherijanto, "Populasi, 11(1), 2000 menuju pembangunan berwawasan kependudukan," vol. 11, no. 1, 2000

[2] L. D. F. E. UI, “Buku Pegangan Bidang Kependudukan.” p. 60, 1980.

[3] United Nations, "World Population Prospects The 2000 Revision Highlights *," Popul. (English Ed., no. February, pp. 1-22, 2001.

[4] Badan Pusat Statistik Indonesia, Proyeksi Penduduk Indonesia Indonesia Population Projection 2010-2035, no. 6. 2013.

[5] Jamaluddin and N. Amalia, Buku Ajar HUKUM PERKAWINAN. 2016

[6] A. Amin, "BKKBN: Nikah ideal itu, 20 tahun bagi wanita, 25 tahun bagi pria," Merdeka.com, 2013. [Online]. Available: https://www.merdeka.com/peristiwa/bkkbn-nikah-ideal-itu-20-tahunbagi-wanita-25-tahun-bagi-pria.html. [Accessed: 26-May-2018]

[7] Badan Penelitian dan Pengembangan Kesehatan, "Riset Kesehatan Dasar (RISKESDAS) 2013,” Lap. Nas. 2013, pp. 1-384, 2013.

[8] Kholilah, "Kawin Siri Pada Masyarakat Madura: Studi Kasus Tentang Faktor Penyebab dan Pengaruh Kawin Siri terhdap Hubungan dalam Keluarga di Desa Buminyar, Kecamatan Tanjung Bumi, Kabupaten Bangkalan," Airlangga University, 2003.

[9] A. Ibrahim, "Urgensi Pernikahan Dini di Desa Labuhan, Kecamatan Sreseh, Kabupaten Sampang,” Surabaya, 2013, pp. 1-14.

[10] Hairi, "FENOMENA PERNIKAHAN DI USIA MUDA DI KALANGAN MASYARAKAT MUSLIM MADURA (Studi Kasus di Desa Bajur Kecamatan Waru Kabupaten Pamekasan)," Universitas Islam Negeri Sunan Kalijaga, 2009.

[11] J. Davis, Kingsley; Blake, "Struktur Sosial dan Fertilitas," Yogyakarta: Lembaga Kependudukan Universitas Gadjah Mada, 1974, pp. 15-73. 
[12] S. S. Arsyad and S. Nurhayati, "Determinan Fertilitas Di Indonesia (Determinant of Fertility in Indonesia)," J. Kependud. Indones., vol. 11, no. 1, pp. 1-14, 2016.
[13] Marieyam, "Pelaksanaan Perkawinan Usia Dini Setelah Berlakunya Undang-Undang No. 1 Tahun 1974 Tentang Perkawinan," Diponegoro University, 2007 